\title{
El negro en ek: Hugo-vertaling nie sonder gebreke
}

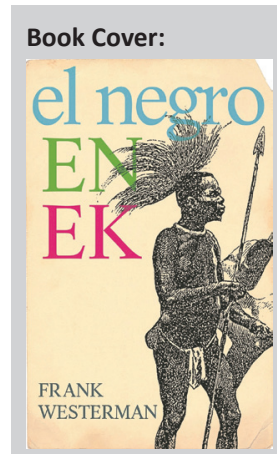

Author:

Frank Westerman

ISBN:

978-1-4853-0753-2

Publisher:

Protea Boekhuis, 2017, R250*

*Book price at time of review

$\square$

Review Title:

El negro en ek: Hugo-

vertaling nie sonder gebreke

Reviewer:

Sonja Loots ${ }^{1}$ (D)

Affiliation:

${ }^{1}$ Department of Afrikaans and

Netherlandic Studies,

University of Cape Town,

South Africa

\section{Corresponding author:}

Sonja Loots,

sonja.loots@uct.ac.za

How to cite this book review: Loots, S., 2018, 'El negro en ek: Hugo-vertaling nie sonder gebreke', Literator 39(1) a1518. https://doi.org/ 10.4102/lit.v39i1.1518

\section{Copyright:}

(C) 2018. The Authors. Licensee: AOSIS. This work is licensed under the Creative Commons Attribution License.

\section{Read online:}

Suid-Afrikaanse lesers moes lank wag vir die Afrikaanse vertaling van Frank Westerman se El Negro en ek (waarvan die oorspronklike publikasie reeds in 2004 verskyn het). Gelukkig is die boek steeds en selfs opnuut ter sake in die lig van debatte oor beeldbestorming, postkoloniale herwaarderings van witmense se houdings teenoor swart liggame, asook hedendaagse besinnings oor etiese kwessies rakende museumuitstallings en dioramas en die hantering van menslike oorskot.

Die boek handel oor Westerman se lewenslange geboeidheid met 'n opgestopte 'KalahariBoesman', slegs bekend as El Negro, wat hy die eerste keer as negentienjarige in 'n museum in Banyoles in Spanje gesien het. Wanneer Westerman jare later in die koerant lees dat daar 'n storm losgebars het oor El Negro se teenwoordigheid in Banyoles se museum, begin hy naspoor hoe dit gekom het dat 'n wit Europëer die lyk van 'n swart Afrikaan soos 'n dier se karkas kon opstop. Hy volg ook die gebeure wanneer El Negro uit die museum in Banyoles verwyder en na Botswana geneem word, en besin oor die implikasies daarvan. Westerman se beskrywing van 'n besoek aan Kaapstad tydens sy navorsing, en sy ontmoeting met Antjie Krog, sal vir Suid-Afrikaanse lesers besonder interessant wees. Dit geld ook raakpunte tussen die lotgevalle van El Negro en dié van Saartjie Baartman. Boonop blyk dit dat El Negro uit Suid-Afrika afkomstig is. Die uitgewer verdien dus 'n pluimpie vir die keuse van die teks, aangesien Westerman se werk ongetwyfeld 'n SuidAfrikaanse lesersgehoor verdien.

Oor die gehalte van die vertaling deur Daniel Hugo kan vrae geopper word. Reeds met die intrapslag, en selfs voordat oorweging geskenk word aan die kruiskulturele en tussentalige kommunikasie tussen Afrikaans en Nederlands, val spelfoute op, byvoorbeeld 'vooroorhel' pleks van 'vooroor hel', 'verderaan' pleks van 'verder aan' en 'gaspacho' pleks van 'gazpacho' (vergelyk die 2017-uitgawe van Afrikaanse Woordelys en Spelreëls en die 2015-uitgawe van Handwoordeboek van die Afrikaans Taal). Hierby kom nie-grammatikale sinskonstruksies ('Maar om ... die resep vir gaspacho te herhaal leer jy nie regtig Spaans nie'); sinskonstruksies waarin die invloed van Engels idiomatiese Afrikaans verdring (bv. die feit dat karakters onder die invloed van die Engelse frase 'I read it in translation' in Hugo-Afrikaans herhaaldelik iets 'in die Engelse vertaling lees' pleks van gewoon die vertaling of vertaalde boek te lees); asook ander sintaksisfoute (soos talle voorbeelde van leesbaarheid wat ingeboet word weens die wegval van grammatiese en prosodiese kommas). Voorts is Hugo se voorsetselgebruik telkens twyfelagtig: die Nederlandse 'uit voorsorg' eerder as die meer gebruiklike Afrikaanse 'as voorsorg(maatreël)'; verskil 'op' hierdie punt pleks van die korrekte 'oor' hierdie punt; tydskrif 'vir' bergsport, eerder as tydskrif 'oor' bergsport. Hierdie slordighede sal enige leser pla, en moet óf deur die vertaler, óf in 'n redigeerproses wat op die vertaling volg, reggestel word.

Dit is onduidelik of Hugo die vertaalstrategie van verinheemsing gekies het, die behoud van vervreemdende elemente in die doeltaal, of vir'n kombinasie hiervan. Dit lyk na laasgenoemde, want kultuurspesifieke inhoude word behou, byvoorbeeld die verwysing na Banyoles se 'bromponiejeug'. In hierdie verband is sekere keuses egter bepaald leessteurend, soos wanneer 'n Spaanse meisie in die Afrikaanse vertaling soos 'n tipiese Nederlander haar stelling eindig met die woord 'hoor': 'Hy is eg, hoor!'. Enige leser wat slegs maar rakelings met Nederlands vertroud is, sal hierdeur gedisoriënteerd voel. Hugo behou telkens Nederlandse woorde wat nie in Afrikaans gebruiklik is nie ('klimwand' pleks van 'klimmuur'); frases wat in Afrikaans nie-idiomaties is, byvoorbeeld die wyse waarop die idiomatiese gebruik van die woord 'toe' by herhaling sneuwel ('die rimpels op sy gesig waaier na alle kante uit'); en frases wat betekeniskognate is, maar anders in Afrikaans as in Nederlands verbind word (bv. die Nederlandse 'vel oor been' pleks van die Afrikaanse idiomatiese frase 'vel en been'). Vertalings uit Nederlands na Afrikaans is telkens nie getrou aan die bronteks nie. Hugo laat die rylopers aan 'n deur 'rammel', wat meer Nederlands as Afrikaans klink: 
Afrikaanse mense 'hamer' aan deure eerder as 'rammel'. Nie een van hierdie woorde klop egter met die oorspronklike Nederlandse woord 'morrelen' nie. Dit sou meer korrek vertaal kon word met 'peuter aan' of 'peuter met'. Ander voorbeelde van nie-korrekte vertalings is: die woord 'toch' (met die betekenis van 'in teenstelling met die voorafgaande') wat as 'uiteindelik' vertaal word; 'daarginds' wat 'daardie' word pleks van 'daar (doer) in die verte' of 'daar diekant'; 'schuivend' wat 'skurend' pleks van 'skuiwend' word; en 'scheren' wat 'skrams verbyjaag' word, terwyl dit veel eerder gaan oor 'snel langs iets gaan'. Registerprobleme duik ook op: Hugo kies die informele 'optel' pleks van 'oplaai', maar gebruik in dieselfde asem 'trokbestuurders' pleks van die meer informele 'trok- of lorriedrywers'. Die 'plunje' van die twee rylopers raak 'bagasie', wat 'n heel ander gevoelswaarde het as die verslete klere en knapsakke of rugsakke van die jong reisigers. Wanneer 'n motor vir hulle stilhou, 'stuiven' hulle daarop af (die teks bevat die verledetydsvorm). Hugo se neutrale 'hardloop' het nie dieselfde gevoelswaarde nie.
Dit sou meer korrek gewees het as hulle in die rigting van die motor 'genael' of 'laat spat' het. Dieselfde voorbehoude geld Hugo se vertaling van El Negro se blik as 'boos'. Omdat 'boos' in Afrikaans sterker klink as in Nederlands, sou 'kwaai' eerder as 'boos' meer korrek gewees het.

Dit is nie die taak van ' $n$ resensent om 'n vertaling te beoordeel deur vlieë te vang en beuselagtige taalfoute of individuele woordkeuses te bevraagteken ten koste van die groter prentjie nie. Wanneer taalfoute, spelfoute, vertaalfoute en sintaksisfoute frekwent voorkom, doen dit egter wel afbreuk aan die vertaling. Alle voorbeelde hierbo kom uit die kort voorwoord en eerste hoofstuk. Hoewel ruimte hier ontbreek vir 'n volledige bespreking van soortgelyke voorbeelde in die res van die teks, is die frekwensie en aard van die probleme wat uitgewys is, na my mening verteenwoordigend van die vertaling in die geheel. Dit is jammer, want Westerman se teks verdien om sonder hindernisse deur Afrikaanse lesers geniet te word. 